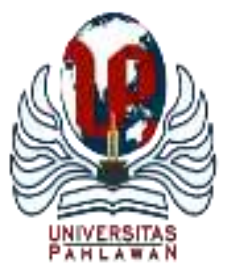

Edukatif : Jurnal Ilmu Pendidikan Volume 3 Nomor 6 Tahun 2021 Halm 4802 - 4809

EDUKATIF: JURNAL ILMU PENDIDIKAN

Research \& Learning in Education

https://edukatif.org/index.php/edukatif/index

\title{
Pengimplementasian Nilai-Nilai Pancasila pada Anak Sekolah Dasar dengan Berlandaskan Metode Contextual Teaching Learning
}

\author{
Silsi Nur Azizah ${ }^{1 凶}$, Siti Fatimah ${ }^{2}$, Dinie Anggraeni Dewi ${ }^{3}$, Yayang Furi Furnamasari ${ }^{4}$
}

Universitas Pendidikan Indonesia, Indonesia 1,2,3,4

E-mail : $\underline{\text { silsinurazizah@upi.edu }}{ }^{1}, \underline{\text { sitifatimahhh@upi.edu }}^{2}, \underline{\text { dinieanggraenidewi@upi.edu }}^{3},{\underline{\text { furi2 } 2810 @ u p i . e d u^{4}}}^{4}$

\begin{abstract}
Abstrak
Nilai - nilai yang terkandung pada pancasila merupakan nilai fondasi serta nilai yang dijadikan acuan dalam kehidupan sehari-hari bangsa Indonesia, maka dari itu pengimplelemtasian nilai Pancasila harus dimulai ketika anak masih usia dini. Sehingga kelak nilai-nilai Pancasila tersebut dapat mendarah daging pada diri anak. Penanaman nilai pancasila pada anak dapat dilakukan melalui pembelajaran pendidikan kewarganegaraan. Agar memaksimalkan tujuan pembelajaran pendidik harus memilih dan menentukan metode serta strategi pembelajaran yang efektif dan efisien. Dengan demikian pembelajaran ini didukung oleh metode Contextual Teaching and Learning, Metode tersebut merupakan metode pembelajaran yang menekankan siswa untuk dapat menghubungkan konsep pengetahuan yang telah diperoleh dengan kehidupan nyatanya. Penelitian ini peneliti menggunakan metode studi literature terhadap beberapa konsep yang berkaitan dengan penelitian ini, serta dengan menggunakan pendekatan kualitatif, dimana setelah menelusuri berbagai sumber peneliti menyimpulkan dalam urairan makna yang dapat dipahami. Dalam mengimplementasi nilai-nilai Pancasila ini tentu tidak selamanya berjalan sesuai rencana, namun terdapat tantangan-tantangan yang menghambat dikarenakan seiring dengan perkembangan zaman yang semakin berkembang. Namun dengan adanya tantangan tersebut sebagai pendidik harus lebih memutar otak agar dapat mengatasi berbagai tantangan yang menghambat dalam pengimplementasian tersebut.
\end{abstract}

Kata Kunci: Nilai Pancasila, Contextual Teaching and Learning, Sekolah Dasar.

Abstract

The values contained in the pancasila are the foundation values and values that are used as acuna in the daily life of the Indonesian nation, therefore the implementation of pancasila values must begin when the child is still early age. So that later the values of Pancasila can be ingrained in children. Planting the value of Pancasila in children can be done through the learning of citizenship education. In order to maximize learning goals educators must choose and determine effective and efficient learning methods and strategies. Thus this learning is supported by contextual teaching and learning methods, it is a method of learning that emphasizes students to be able to connect the concept of knowledge that has been obtained with real life. This research researcher used the method of study literature to several concepts related to this study.as well as by using a qualitative approach, where after tracing various sources researchers conclude in anurairan of understandable meaning. In implementing the values of Pancasila is certainly not always going according to plan, but there are challenges that add up because along with the development of the times that are growing. But with these challenges as educators must be more brain-twisted in order to overcome various challenges that hinder in implementing it.

Keywords:Pancasila values, Contextual Teaching and Learning, Primary school.

Copyright (c) 2021 Silsi Nur Azizah, Siti Fatimah, DinieAnggraeni Dewi, YayangFuri Furnamasari

$\square$ Corresponding author

Email : silsinurazizah@upi.edu

DOI : https://doi.org/10.31004/edukatif.v3i6.1547

ISSN 2656-8063 (Media Cetak)

ISSN 2656-8071 (Media Online)

Edukatif : Jurnal Ilmu Pendidikan Vol 3 No 6 Tahun 2021 p-ISSN 2656-8063 e-ISSN 2656-8071 
4803 Pengimplementasian Nilai-Nilai Pancasila pada Anak Sekolah Dasar dengan Berlandaskan Metode Contextual Teaching Learning - Silsi Nur Azizah, Siti Fatimah, DinieAnggraeni Dewi, YayangFuri Furnamasari

DOI: https://doi.org/10.31004/edukatif.v3i6.1547

\section{PENDAHULUAN}

Pancasila merupakan tumpuan negara dan sebagai fondasi kepribadian bangsa, sehingga dengan hal tersebut nilai-nilai yang terkandung dalam pancasila harus tercermin dalam kehidupan berbangsa dan bernegara. Pancasila sebagai fondasi kepribadian bangsa, dan citranya terwujud dalam segala tingkah laku, sikap, dan perilaku seluruh warga negara berdasarkan Pancasila. Nilai-nilai yang termuat pada Pancasila berada dalam kerangka kebhinekaan, artinya Pancasila hidup pada kebhinekaan Indonesia dalam hal agama, ras, budaya, bahasa serta aspek lainnya. Tetapi keberagaman tersebut dapat dipersatukan dengan keberadaan pancasila.Begitu pula pendidikan di Indonesia harus berlandaskan pada nilai-nilai pancasila, agar dapat mengembangkan potensi yang ada pada siswa dan dapat membentuk siswa yang beriman kepada Tuhan Yang Maha Esa, berbudi pekerti, mandiri, berilmu, kreatif dan tanggung jawab.

Namun jika kita melihat pada kenyataannya, pada zaman saat ini kerap kali ditemukan problematikan anak-anak yang moralnya rusak. Hal tersebut diakibatkan karena pengaruh dari perkembangan zaman dengan teknologi yang semakin canggih serta akibat dampak buruk dari globalisasi. Keadaan tersebut menjadi perhatian dunia pendidikan. Dimana pendidikan harus melakukan tindakan agar dapat mengatasi problematika tersebut. Salah satunya dalam pendidikan harus menanamkan pembiasaan kehidupan dengan berlandaskan nilai-nilai pancasila agar dapat membentuk manusia yang berakhlak mulia dan bermoral baik. (Efendi, Y., \& Sa'diyah, 2020) memaparkan pada bidang pendidikan pancasila bisa dijadikan acuan dalam menyaring perkembangan teknologi dan budaya luar yang masuk ke Indonesia, sehingga dengan penyaringan tersebut dapat meminimalisir dampak buruk yang terjadi pada anak.

Untuk menjamin keberlangsungan kehidupan bangsa ini, kita sebagai pendidik harus berusaha keras untuk memaksimalkan dalam penanaman nilai-nilai pancasila dalam kehidupan generasi muda, khususnya anak sekolah dasar. Karena pada usia sekolah dasar merupakan tahapan awal dalam perkembangan semua aspek seperti kepribadian, perkembangan moral, dan jati dirinya. Sehingga dengan penanaman nilai-nilai yang baik bagi anak setidaknya dapat meminimalisir dampak buruk dari pengaruh perkembangan zaman saat ini. Dan nilai-nilai pancasila ini dapat melekat dan mendarah daging pada diri anak sehingga menjadi acuan dalam bersikap dan perilaku kesehariannya.

Penerapan nilai-nilai pancasila pada anak sekolah dasar dapat dilaksanakan melalui pembelajaran pendidikan kewarganegaraan (Nurizka, R., \& Rahim, 2020). Karena dalam pembelajaran pendidikan kewarganegaraan ini pada dasarnya menjadi acuan dalam membentuk warga negara khususnya generasi muda dalam membedakan dan merealisasikan hak dan kewajibannya. Begitu pula dengan penanaman nilai-nilai pancasila, pada pendidikan kewarganegaraan lah dapat menanaman dan mendorong anak untuk merealisasikan nilai-nilai tersebut. Namun, dewasa ini pada satuan pendidikan sekolah dasar masih dapat dikatakan belumberhasil dalam menerapkan nilai-nilai pancasila tersebut, maka dari itu agar mencapai akan keberhasilan tersebut perlunya strategi dan metode pembelajaran yang digunakan harus tepat dalam penanaman nilai tersebut dalam pembelajaran pendidikan kewarganegaraan ini. Motede pembelajaran yang cocok digunakan dalam pembelajaran pendidikan kewarganegaraan mengenai mengimplementasikan nilainilai pancasila dalam kehidupan sehari hari yakni metode pembelajaran Contextual Teaching Learning, model pembelajaran ini dikembangkan pada pembelajarn ini karena dirasa selaras dengan karakteristik materi yang diajarkan kepada siswa sehinga diharapkan dapat mencapai tujuan pembelajaran yang lebih efektif dan efisien (Hasnidar, H., \& Elihami, 2020).

Model pembelajaran Contextual Teaching Learning ini merupakan model pembelajaran menitikberatkan keterkaitan serta menghubungkan antara pengetahuan yang diperoleh selama pembelajaran dan diaktualisasikan dalam kehidupan sehari-hari. Dalam praktik proses pembelajaran guru bia menghubungkan konten yang dibahas dengan pengalaman-pengalaman yang dialami siswa itu sendiri. 
4804 Pengimplementasian Nilai-Nilai Pancasila pada Anak Sekolah Dasar dengan Berlandaskan Metode Contextual Teaching Learning - Silsi Nur Azizah, Siti Fatimah, DinieAnggraeni Dewi, YayangFuri

Furnamasari

DOI: https://doi.org/10.31004/edukatif.v3i6.1547

(Sawitri, 2017) memaparkan pada proses pembelajaran siswa lebih banyak aktif untuk mengeksplor pengetahuannya secara mendiri, sehingga pembelajaran akan dirasa lebih bermakna. Karena ketika siswa dapat menemukan konsep secara mandiri, siswa tersebut akan lebih mudah dalam memahami dan dapat mengingat dalam jangka waktu yang lama.

Menurut (Winarno., 2012) dalam bukunya menjelaskan bahwa dalam pembelajaran berlandaskan kontekstual ini, agar dapat mencapai apa yang sudah menjadi tujuan pembelajaran yaitu dapat merealisasikan atau mengimplementasikan daripada nilai-nilai pancasila, maka dalam pembelajaran kontekstual ini harus memenuhi beberapa komponen, yakni (1) kontruktivisme, menciptakan pembelajaran yang bermakna, dimana pembelajaran difokuskan untuk dapat mengembangkan intelektual dan konseptual, siswa dituntut untuk menemukan konsep pengetahuan secara mandiri. Pada proses ini pendidik berperan untuk mendorong serta mengarahkan siswa untuk menemukan makna baru dari pengetahuan yang telah dipelajari. (2) Inkuiri, pada komponen ini siswa diharapkan bisa menemukan apa jalan keluar dari permasalahan yang dibahas dengan penekanan berfikir secara kritis. Proses ini bisa dilakukan melalui komunikasi atau diskusi atau tanya jawab dengan pendidik, sehingga pendidik dapat menyimpulkan sejauh mana kemampuan siswa. (3) Questioning ( bertanya ), bertanya pada proses disini ditujukan agar pendidik dapat menggali dan mendorong rasa ingin tahu siswa akan sesuatu. (4) Masyarakat belajar, pada komponen ini pendidik mendorong siswa untuk bekerjasama dengan siswa lain guna mendiskusikan apa yang lelah dipeloreh dari masing-masing siswa, sehingga konsep ataupun jalan keluar yang telah di temukan bisa saling melengkapi satu sama lain. Karena setiap siswa tentu berbeda dalam hal kemampuannya. (5) Pemodelan, dalam pemudolan ini pendidik dapat menghadirkan contoh dari materi yang sedang dibahas, namun dalam pemodelan tidak hanya pendidik saja namun bisa juga melibatkan siswa itu sendiri. (6) Refleksi, pada komponen ini dapat dilakukan secara bersama sama antara guru dan siswa untuk menyimpulkan apa yang telah menjadi bahasan serta pendidik memberikan penjelasan sebagai penguatan mengena konsep yang telah ditemukan oleh siswa. Dan (7) Penilaian/evaluasi, penilaian ini menjadi tolak ukur dari keberhasilan pembelajaran yang telah dilaksanakan, sehingga menjadi evaluasi untuk perubahan pembelajaran berikutnya.

Penerapan pembelajaran dengan berlandaskan metode Contextual Teaching Learning ini diharapkan dapat berjalan secara efektif dan efesien sehingga dapat mencapai apa yang menjadi tujuan dari pembelajaran yaitu lebih meningkatkan kepekaan guru dan siswa dalam mengimplementasikan nilai-nilai pancasila dalam kehidupan sehari hari pada anak sekolah dasar .

\section{METODE PENELITIAN}

Dalam penelitian ini, peneliti melakukan penelitian dengan metode studi literature terhadap beberapa konsep yang berkaitan dengan penelitian ini. Instrument dalam penelitian adalah peneliti sendiri, dimana semua data-data yang diperoleh merupakan hasil penelusuran yang tentunya memiliki kualitas dalam maknamakna. Analisis penelitian yang digunakan dalam penelitian ini yaitu pendekatan kualitatif, dimana setelah menelusuri berbagai sumber peneliti menyimpulkan dalam urairan makna yang dapat dipahami. Konsepkonsep dijabarkan oleh peneliti secara deskripsi dari hasil studi literature dengan membaca berbagai sumber yang relevan dan berkaitan yang bermula dengan membaca teori, menganalisis, memahami dan kemudian menyimpulkan secara terpadu.

\section{HASIL DAN PEMBAHASAN PENELITIAN}

Guna mempersiapkan peserta didik yang mumpuni dalam menjalani kehidupan sosial, berbangsa dan bernegara, setiap peserta didik dibekali ilmu-ilmu pengetahuan yang diberikan dalam satuan lembaga 
4805 Pengimplementasian Nilai-Nilai Pancasila pada Anak Sekolah Dasar dengan Berlandaskan Metode Contextual Teaching Learning - Silsi Nur Azizah, Siti Fatimah, DinieAnggraeni Dewi, YayangFuri Furnamasari

DOI: https://doi.org/10.31004/edukatif.v3i6.1547

pendidikan. Tak hanya peserta didik sekolah dasar, semua jenjang pendidikan berusaha mengoptimalkan segala kebutuhan guna menunjangg enerasi bangsa yang berbangsa dan bernegara serta memeliki nilai moral yang baik. Dalam satuan pendidikan, para peserta didik dibekali materi Pendidikan Kewarganegaraan. Pemberian materi ini diharapkan dalam menanamkan peserta didik agar lebih mencintai bangsanya dan mau menerapkan dasar negara yang dicerminkan dalam bentuk penerapan kehidupan sehari-hari. Dalam menjalankan kehidupan berbangsa dan bernegara, tentunya kehidupan ini di dasarkan pada suatu pandangan yaitu Pancasila. Pancasila harus diterapkan kepada peserta didik sejak dini terlebih pada usia sekolah dasar agar nantinya mereka dapat menjalankan kehidupan yang sebanarnya sesuai dengan pedoman-pedoman yang ada. Agar pembelajaran Pendidikan kewarganegaraan di satuan pendidikan sekolah dasar dapat berjalan dengan baik, tentunya dibutuhkan seorang pendidik yang memiliki kemampuan yang tinggi dalam mengemas pembelajaran yang mudah dipahami oleh peserta didik.

Dari hasil penelitan yang dilakukan, pengimplementasian nilai-nilai Pancasila dalam mata pelajaran Pendidikan Kewarganegaraan di Sekolah dasar dapat dilakukan dengan mengemas pembelajaran melalui model pembelajaran kontekstual (Contextual Teaching Learning). Hal ini selaras dengan pendapat (Parhan, M., \& Sukaenah, 2021) yang menyatakan bahwa, model pembelajaran kontekstual dianggap mampu menunjang pembelajaran implementasi nilai-nilai Pancasila. Model pembelajaran kontekstual dinilai efektif karena pembelajaran ini memandang bahwa proses pembelajaran yang baik harus mampu menghubungkan kebermaknaan antara pemikiran yang ada dengan penerapan praktis-praktis yang sebenernya diperlukan dalam kehidupan dunia nyata. Pembelajaran Contextual teaching and learning ini mengkolaborasikan antara materi pelajaran dan keterampilan intelektual yang harus dimiliki peserta didik dalam pengeimplementasian nya pada suatu kondisi dan situasi yang cocok dengan psikologi, kognitif dan lingkungan peseta didik. Psikologi konitif peserta didik akan menginterpretasikan materi- materi yang diberikan pendidik pada subjeksubjek nyata kehidupan mereka yang berkaitan dengan kehidupan pribadi, sosial dan budaya (Johnson, 2011).

Model pembelajaran contextual teaching \& learning memiliki cirri yaitu 1) kerjasama, 2) menekankan pada pentingnya pemecahan suatu masalah, 3)berimplikasi pada keragaman konteks kehidupan peserta didik yang berbeda-beda, 4) bersifat menunjang, 5) menyenangkan, 6) semangat dalam belajar, 7) terintegrasi, 8) menggunakan berbagai sumber, 9) peserta didik yang aktif, 10) diskusi dengan teman, 11) peserta didik yang kritis, 12) guru yang kreatif, 13) laporan pembelajaran yang lengkap disertai hasil karya dari peserta didik Pada penerapannya, model pembelajaran contextual teaching \& learning yang digunakan dalam pembelajaran Pendidikan Kewarganegaraan mengenaiimplementasi nilai-nilai Pancasila memiliki langkah-langkah sebagai berikut: 1) mengembankan pemikiran jika anak akan belajar lebih bermakna apabila mereka bekerja sendiri, mencari sendiri, dan mengkontruksi sendiri, 2) melakukan kegiatan inkuiri pada setiap topik, 3) mengembangkan rasa ingin tahu siswa dengan bertanya, 4) menciptakan kolaborasi belajar kelompok, 5) menggunakan model sebagai contoh perumpamaan dari pembelajaran, 6) melakukan refleksi, 7) melakukan penilaian dengan beragamcara (Tampubolon, 2013). Dengan menerapkan metode pembelajaran yang baik tentunya akan mendorong peserta didik dalam penerapan pada kehidupan sehari-hari. Hal ini menunjukkan bahwa metode contextual teaching \& learning bertujuan bukan untuk dipahami saja materinya, melainkan bagaimana siswa menerapkan dalam kehidupan keseharian mereka. Karena pada dasarnya materi nilai-nilai Pancasila yang diajarkan melalui model pembelajaran Contextual Teaching \& Learning diajarkan bukan hanya sekedar konsep pengetahuan saja, melainkan langsung pada penerapan aplikasi dunia nyata.Sebelum melakukan proses pembelajaran seorang pendidik harus membuat persiapan yang matang. Salah satu persiapan nya yaitu membuat rencana pelaksanaan pembelajaran yang memuat materi mengenai implementasi nilai-nilai Pancasila. Setelah menyusun rencana pelaksanaan pembelajaran, maka pendidik dapat menerapkannya dengan menggunakan metode ceramah, penugasan, ataupun Tanya jawab dan diskusi kelompok yang berkaitan dengan penerapan implementasi nilai-nilai Pancasila. Proses selanjutnya yaitu 
4806 Pengimplementasian Nilai-Nilai Pancasila pada Anak Sekolah Dasar dengan Berlandaskan Metode Contextual Teaching Learning - Silsi Nur Azizah, Siti Fatimah, DinieAnggraeni Dewi, YayangFuri Furnamasari

DOI: https://doi.org/10.31004/edukatif.v3i6.1547

tindakan, dalam tindakannya seorang pendidik harus mengacu pada rancangan pelaksanaan pembelajaran yang telah disusun sebelumnya dengan menggunakan langkah-langkah yang sistematis dan juga terfokus pada kegiatan pembelajaran antara pendidik dan juga peserta didik guna mencapai tujuan yang telah direncanakan. (Nurdyansyah, N., \&Fahyuni, 2016) Pada kegiatan awal, seorang pendidik dapat memulai pembelajaran dengan memulai melalui berdoa. Kegiatan berdoa ini dapat meningkatkan nilai spiritual pesertadidik yang sejalan dengan implementasi nilai-nilai Pancasila pada sila pertama. Tak lupa seorang pendidik juga harus memberikan motivasi dan menyampaikan tujuan pembelajaran yang akan dicapai oleh peserta didik.

Pada kegiatan inti pembelajaran seorang pendidik harus mampu menciptakan suasana kelas yang melibatkan keaktifan peserta didik. Untuk memancing peserta didik agar aktif dalam berdiskusi maka pendidik dapat memberikan stimulus sebagai rangsangan awal guna pengetahuan peserta didik. Materi implementasi nilai-nilai Pancasila diberikan dengan konsep diskusi aktif pada peserta didik yang mengkaitkan dengan implementasi pada kehidupan nyata. Peserta didik diperintahkan untuk menyebutkan implementasi nilai-nilai Pancasila apa saja yang diterapkan dalam kehidupan sehari-hari. Diskusi dimulai dari implementasi nilai kesatu, dua, tiga, empat, dan lima. Setelah peserta didik aktif dalam menyebutkan implementasi nilainilai Pancasila pada kehidupan sehari-hari, guru juga memberikan penguatan atas jawaban yang telah didiskusikan oleh peserta didik. Dan pendidik juga memberikan implementasi dari adanya diskusi pada pembelajaran yang berkaitan dengan implementasi nilai-nilai Pancasila yaitu musyawarah mufakat. Sebisa mungkin seorang pendidik memberikan implementasi yang dimulai pada ruang lingkup terdekat peserta didik. Setelah kegiatan diskusi selesai guru memberikan kesimpulan mengenai implementasi nilai-nilai Pancasila dalam kehidupan sehari-hari juga member penguatan kepada peserta didik bahwa Pancasila sebagai dasar negara harus dijadikan pandangan hidup dalam berbangsa dan bernegara. Sebelum menutup pembelajaran, pendidik mengarahkan peserta didik untuk berdoa terlebih dahulu yang dilakukan secara khidmat.

Pancasila merupakan dasar negara bangsa Indonesia yang dijadikan pandangan hidup dalam bernegara. Nilai-nilai yang ada pada pancasila ini harus kita jadikan pedoman dalam melakukan kehidupan sehari-hari. Nilai-nilai yang terkandung pada pancasila tentu harus ditanamkan pada diri anak mulai usia dini, agar kelak nilai-nilai pancasila tersebut mendarah daging pada diri anak dan menjadi acuan dalam kehidupan sehari-hari (Asmaroini, 2016). Selain itu, penanaman nilai pancasila pada anak usia dini ditujukan untuk mempersiapkan menjadi penerus bangsa yang memiliki karakter moral yang sesuai dengan pancasila.

Pancasila terdiri dari lima nilai dasar yang setiap silanya mengandung pedoman-pedoman kehidupan bangsa Indonesia. adapun nilai-nilai yang terkandung pada pancasila adalah sebagai berikut :

(1) Ketuhanan Yang Maha Esa, pada sila ketuhanan yang maha esa ini mengandung makna bahwa berdirinya sebuah negara merupakan wujud dari kehidupan manusia sebagai makhluk tuhan yang maha esa. Hal ini mengandung arti bahwa segala sesuatu yang berhubungan dengan pelaksanaan sebuah negara harus berlandaskan nilai-nilai ketuhanan, baik itu penyelenggaraan moral negara, pemerintahan negara, politik, hukum serta peraturan perundang-undangan. Dari makna tersebut implementasi yang harus ditanamkan pada diri peserta didik yakni (a) percaya akan adanya keberadaan Tuhan Yang Maha Esa (b) bertaqwa kepada tuhan yang maha esa (c) bebas dalam memeluk agama yang dianut sesuai dengan kepercayaan (d) keterbukaan umat beragama (e) mencintai terhadap semua makhluk ciptaan tuhan. Adapun implementasi pada lingkungan sekolah diantaranya : (a) Berdoa sebelum dan setelah pembelajaran (b) saling menghormati teman dan guru yang berbeda keyakinan (c) hidup rukun dengan teman yang berbeda keyakinan (d) tidak menjadikan alasan berbeda agama untuk berteman. (e) menyayangi dan merawat binatang serta tumbuh-tumbuhan.

(2) Kemanusiaan yang adil dan beradab, pada sila kemanusiaan yang adil dan beradab mengandung makna bahwa keberadaan sebuah negara harus mengutamakan harkat dan martabat manusia sebagai makhluk yang beradab. oleh karena itu dalam sila ini menyadarkan kita akan sikap moral dan tingkah laku harus berlandaskan pada norma-norma serta kebudayaan baik untuk diri sendiri, manusia lain ataupun lingkungan 
4807 Pengimplementasian Nilai-Nilai Pancasila pada Anak Sekolah Dasar dengan Berlandaskan Metode Contextual Teaching Learning - Silsi Nur Azizah, Siti Fatimah, DinieAnggraeni Dewi, YayangFuri

Furnamasari

DOI: https://doi.org/10.31004/edukatif.v3i6.1547

sekitarnya. Dari makna tersebut implementasi yang harus ditanamkan pada diri peserta didik, yakni : (a) menjunjung tinggi nilai kejujuran (b) mengutamakan kesamaan derajat antar sesama manusia (c) mencerminkan perilaku keberadaban. adapun implementasi yang harus ditanamkan pada diri anak dilingkungan sekolah (a) sopan santun terhadap teman dan guru. (b) menolong teman yang membutuhkan bantuan (c) mengembangkan sikap tenggang rasa (d) berani membela kebenaran serta keadilan (e) tidak bersikap seenaknya kepada teman.

(3) Persatuan indonesia, pada sila ini mengandung makna bahwa kita harus menyadari secara kodrati manusia merupakan makhluk individu sekaligus makhluk sosial. maka dari itu manusia memiliki keberagaman karakteristik baik itu suku, ras, golongan, maupun kepercayaan. hal ini menunjukan bahwa walaupun manusia memiliki keberagaman tetapi kita harus hidup dalam satu kesatuan. Dari makna tersebut implementasi yang harus ditamankan pada peserta didik yakni : (a) menjunjung tinggi nilai persatuan (b) menjalani hidup dengan kebersamaan (c) mencintai tanah air dengan sepenuh jiwa (d) hidup bersatu diatas keberagaman. adapun implementasi yang harus ditanamkan pada peserta didik dilingkungan sekolah diantaranya : (a) merelakan jiwa dan raga demi kepentingan bangsa dan negara (b) melaksanakan upacara bendera setiap hari senin (c) hafal serta mengetahui lagu-lagu nasional (d) merayakan hari kemerdekaan (e) menjaga kerukunan diantara warga sekolah (f) mengutamakan kepentingan bersama dibandingkan kepentingan pribadi (g) mempelajari sejarah perjuangan bangsa sebagai bentuk menghargai jasa para pahlawan.

(4) Kerakyatan yang dipimpin oleh hikmah kebijaksanaan dalam permusyawaratan perwakilan. Sila ini mengandung makna bahwa dalam kehidupan kita tidak bisa semena-mena dalam mengambil keputusan, tetapi harus berdasarkan hasil musyawarah mufakat, serta dalam pelaksanaan negara kekuasaan berada ditangan rakyat dan dalam penyelenggaraannya harus mengandung nilai demokrasi. dari makna tersebut implementasi yang harus ditanamkan adalah sebagai berikut : (a) menjunjung tinggi nilai kerakyatan (b) melakukan musyawarah ketika menyelesaikan suatu persoalan hingga mencapai mufakat bersama (c) memiliki hak yang sama dalam mengambil keputusan (d) tidak boleh memaksakan kehendak orang lain . adapun implementasi yang harus ditanamkan pada peserta didik di lingkungan sekolah, diantaranya : (a) menghargai pendapat teman (b) mengikuti diskusi kelas (c) berani dalam menyampaikan pendapat ketika sedang diskusi (d) mendengarkan pendapat teman dan guru (e) tidak memaksakan kehendak pribadi (f) memutuskan suatu persoalan dengan penuh tanggung jawab. (Fatimah, S., \& Dewi, 2021).

(5) Keadilan sosial bagi seluruh rakyat Indonesia, sila kelima ini mengandung makna bahwa suatu negara harus mengedepankan nilai keadilan dan kesejahteraan rakyat, hal ini ditunjukan pada keterikatan keyakinan dan sikap dalam mewujudkan nilai-nilai keadilan dan kesejahteraan. dari makna tersebut implementasi yang harus ditanamkan pada peserta didik, yakni : (a) menjunjung tinggi sikap keadilan (b) mengedepankan kesejahteraan lahir dan batin (c) hidup dengan rasa kekeluargaan dan gotong royong (d) semangat kerja untuk mencapai kesejahteraan hidup. adapun implementasi yang harus ditanamkan pada lingkungan sekolah, diantaranya : (a) menciptakan suasana kelas dengan penuh rasa kekeluargaan (b) mengikuti kegiatan kerja bakti yang diadakan disekolah (c) bersikap adil terhadap semua teman di sekolah (d) bekerja keras untuk mencapai prestasi (e) menghormati hak-hak teman (f) menghargai hasil karya teman.

Menurut (Antari, L. P. S., \& De Liska, 2020) dalam mengimplementasikan nilai-nilai pancasila tentunya tidak mudah dan selalu mendapatkan tantangan, terlebih pada saat ini beriringan dengan berkembangnya zaman tentu akan membawa pengaruh buruk terhadap tatanan kehidupan bangsa dan negara. Akibat dari adanya perkembangan tersebut membuat semakin memudarnya nilai-nilai pancasila dalam kehidupan manusia. Oleh karena itu bangsa Indonesia harus mampu mengembangkan kewaspadaan nasional dan ketahanan serta ideologi bangsa . Kesanggupan dalam menghadapi segala tantangan yang ada, maka kita harus memiliki pondasi yang kuat yaitu kepercayaan nasional terhadap dasar negara pancasila sebagai solusi 
4808 Pengimplementasian Nilai-Nilai Pancasila pada Anak Sekolah Dasar dengan Berlandaskan Metode Contextual Teaching Learning - Silsi Nur Azizah, Siti Fatimah, DinieAnggraeni Dewi, YayangFuri

Furnamasari

DOI: https://doi.org/10.31004/edukatif.v3i6.1547

dalam menghadapi tantangan perkembangan zaman saat ini. maka dari itu, pancasila bisa dijadikan sebagai alat dalam menyaring dampak dari perkembangan zaman sehingga bisa meminimalisir tantangan yang menghambat dalam pengimplementsian nilai pancasila. (Sugianto, B., Taena, L., \& Bilu, 2019) memaparkan tantangan dalam mengimplementasikan nilai-nilai pancasila di era yang mengalami segala perkembangan dapat mengusut eksistensi kepribadian bangsa, secara sadar tidak sadar saat ini Indonesia berada pada perubahan arus globalisasi. Namun wajib kita ingat, bangsa indonesia seharusnya tidak untuk kehilangan jati dirinya, dan harus mampu menyeimbangkan atas perubahan arus tersebut.

Dari berbagai tantangan yang menyebabkan serta menghambat dalam pengimplementasian nilai-nilai pancasila, menurut (Jiwandono, I. S., \& Nurbeni, 2019) dibutuhkan suatu gerakan untuk memberantas tantangan tersebut sehingga penanaman nilai pancasila pada peserta didik dapat berjalan semestinya. Penanaman niai-nilai pancasila untuk peserta didik dikemas dalam pembelajaran kewarganegaraan, maka yang menjadi solusi dalam mengatasi tantangan tersebut peran guru sangat penting dan sangat dibutuhkan. Dimana pendidik harus lebih memutar otak agar dapat menciptakan pengemasan pembelajaran yang efektif dan efisien agar mencapai tujuan daripada pembelajaran yang dilaksanakan yakni agar pengimplementasian nilai-nilai pancasila pada peserta didik sekolah dasar dapat terealisasikan dengan baik. Dalam hal ini pendidik ditutuntut untuk lebih kreatif dan inovatif lagi dalam memilih metode, pendekatan serta strategi yang digunakan pada saat pembelajaran. Menurut (Hosnan, 2014) mengungkapkan Contextual teaching learning merupakan salah satu opsi dalam memaksimalkan pembelajaran penanaman/ implementasi nilai-nilai pancasila ini, karena metode tersebut dianggap selaras dengan aa yang menjadi tujuan pembelajaran, diman nantinya siswa tidak hanya tahu dalam bentuk pengetahuan saja, namun peserta didik dapat menghubungkan atau merealisasikan pada kehidupan sehari-harinya. Dengan demikian sebagai pendidik harus lebih mematangkan konsep pembelajaran tersebut agar bisa merealisasikan pengimplementasian nilai-nilai pancasila tersebut dan dapat mengatasi tantangan yang menjadi hambatan dalam merealisasikannya.

\section{KESIMPULAN}

Pancasila merupakan identitas jati diri bangsa Indonesia. Pancasila dijadikan pedoman hidup guna pelaksaan kehidupan berbangsa dan bernegara. Hal ini menunjukkan bahwa Pancasila harus diimplementasikan secara penuh dalam kehidupan nyata. Dalam kenyataanya, tentunya banyak sekali tantangan yang dihadapi dalam pengimplementasian nilai-nilai Pancasila ini. Dengan adanya tantangan tersebut, maka nilai-nilai Pancasila ini harus ditanamkan pada anak sedini mungkin. Pengimplementasian nilai-nilai Pancasila dapat ditanamankan sejak anak usia dini, terlebih pada siswa Sekolah Dasar. Usia sekolah dasar merupakan usia dalam fase emas atau golden age. Dalam menerapkan implementasi nilai-nilai Pancasila pada siswa, materi dapat dikemas dalam mata pelajaran PKn. Guna melaksanakan pembelajaran tersebut, dapat pula dilakukan dengan model pembelajaran Contextual teaching \& learning. Model pembelajaran ini dinilai sangat efektif dalam penerapannya karena melibatkan diskusi keaktifan siswa juga implementasi pada kehidupan nyata. Tentunya, dengan adanya implementasi pada dunia nyata akan mempermudah siswa dalam menangkap nilai-nilai implemtasi Pancasila yang ada.

\section{UCAPAN TERIMA KASIH}

Puji dan syukur kami panjatkan kepada Tuhan Yang Maha Esa karena atas rahmat dan hidayahnya peneliti dapat menyelesaikan penelitian berdasarkan studil iteratur yang berjudul "Pengimplementasian NilaiNilai Pancasila pada Anak Sekolah Dasar dengan Metode Contextual Teaching Learning”. Tak lupa peneliti ucapkan terima kasih kepada semua pihak yang telah terlibat dalam penelitian ini. 
4809 Pengimplementasian Nilai-Nilai Pancasila pada Anak Sekolah Dasar dengan Berlandaskan Metode Contextual Teaching Learning - Silsi Nur Azizah, Siti Fatimah, DinieAnggraeni Dewi, YayangFuri Furnamasari

DOI: https://doi.org/10.31004/edukatif.v3i6.1547

\section{DAFTAR PUSTAKA}

Antari, L. P. S., \& De Liska, L. (2020). Implementasi Nilai Nilai Pancasila Dalam Penguatan Karakter Bangsa.Widyadari: Jurnal Pendidikan. Jurnal Pendidikan, 2, 676-687.

Asmaroini, A. P. (2016). Implementasi Nilai-Nilai Pancasila Bagi Siswa Di Era Globalisasi. Citizenship Jurnal Pancasila Dan Kewarganegaraan. Jurnal Pancasila Dan Kewarganegaraan, 2, 440-450.

Efendi, Y., \& Sa'diyah, H. (2020). Penerapan Nilainilai Pancasila Dalam Lembaga Pendidikan. Jurnal Pancasila Dan Kewarganegaraan, 5, 54-65.

Fatimah, S., \& Dewi, D. A. (2021). Pengimplementasian Nilai-Nilai Pancasila Dalam Membangun Karakter Jati Diri Anak Bangsa. Antropocene: Jurnal Penelitian Ilmu Humaniora, 1.

Hasnidar, H., \& Elihami, E. (2020). Pengaruh Pembelajaran Contextual Teaching Learning Terhadap Hasil Belajar Pkn Murid Sekolah Dasar. Jurnal Pendidikan Guru Sekolah Dasar, 1, 42-47.

Hosnan. (2014). Pendekatan Saintifik Dan Kontekstual Dalam Pembelajaran Abad 21 Kunci Sukses Implementasi Kurikulum 2013.

Jiwandono, I. S., \& Nurbeni, I. (2019). Persepsi Mahasiswa Terhadap Fungsi Pancasila Sebagai Weltanschauung Dalam Upaya Mengatasi Merosotnya Nilai Kebangsaan. Else (Elementary School Education Journal): Jurnal Pendidikan Dan Pembelajaran Sekolah Dasar, 3(35-42).

Johnson, E. B. (2011). Ctl: Contextual Teaching \& Learning: MenjadikankegiatanbelajarMengajarmengasikan Dan Bermakna.

Nurdyansyah, N., \&Fahyuni, E. F. (2016). Inovasi Model Pembelajaran Sesuai Kurikulum 2013.

Nurizka, R., \& Rahim, A. (2020). Internalisasi Nilainilai Pancasila Dalam Membentuk Karakter Siswa Melalui Budaya Sekolah. Elementary School: Jurnal Pendidikan Dan Pembelajaran Ke-Sd-An, 7, 38 49.

Parhan, M., \& Sukaenah, S. (2021). Pendekatan Kontekstual Dalam Meningkatkan Pembelajaran Pendidikan Pancasila Dan Kewarganegaraan Di Sekolah Dasar. Jurnal Ilmiah Pendidikan Pancasila Dan Kewarganegaraan, 5, 360-368.

Sawitri, N. P. E. (2017). Penerapan Pendekatan Pembelajaran Kontekstual Untuk Meningkatkan Keaktifan Dan Hasil Belajar Pkn Kelas V Sd Negeri 3 Sebatu Gianyar. Mimbar Pgsd Undiksha, 1.

Sugianto, B., Taena, L., \& Bilu, L. (2019). Implementasi Pancasila Tantangan Dan Solusinya. Gema Pendidikan, 2, 10-19.

Tampubolon, B. (2013). Penerapan Pendekatan Kontekstual Untuk Meningkatkan Hasil Belajar Pendidikan Kewarganegaraan Siswa Kelas Iv Sd. Jurnal Pendidikan Dan Pembelajaran Khatulistiwa, 9.

Winarno. (2012). Pembelajaran Pendidikan Kewarganegaraan. Jakarta: Bumi Aksara. 